UDC: $316.344(481)^{\text {" } 20 / 21 " ~}$

DOI : $10.24919 / 2519-058 x .15 .204968$

\begin{abstract}
Nataliia ZALIETOK
PhD (History), Senior Research Fellow of the Sector for Archives Preservation Technologies Development of the Department for Archival Affairs Technological Support of the Ukrainian Research Institute of Archival Affairs and Record Keeping, 24 Solomyanska Street, Kyiv, Ukraine, postal code 03110 (nataliazaletok@gmail.com)
\end{abstract}

ORCID: https://orcid.org/0000-0002-5319-3876

ResearcherID: C-6544-2018 (http://www.researcherid.com/rid/C-6544-2018)

\title{
Наталія ЗАЛЕТОК
}

кандидат історичних наук, стариий науковий співробітник сектору розроблення технологій забезпечення збереженості архівних документів відділу технологічного забезпечення архівної справи Українського науково-дослідного інституту архівної справи та документознавства, вул. Солом'янська, 24, м. Київ, Украӥна, 03110 (nataliazaletok@gmail.com)

Бібліографічний опис статті: Zalietok, N. (2020). The models of work-life balance in Norway at the end of the XXth century - the beginning of the XXIst century in the context of gender equality. Skhidnoievropeiskyi Istorychnyi Visnyk [East European Historical Bulletin], 15, 220-229. doi: 10.24919/2519-058x.15.204968

\section{THE MODELS OF WORK-LIFE BALANCE IN NORWAY AT THE END OF THE XXth CENTURY - THE BEGINNING OF THE XXISt CENTURY IN THE CONTEXT OF GENDER EQUALITY}

\begin{abstract}
The aim of the research is to describe, to analyse and to compare different models of the work-life balance, which were implemented in Norway to remove the gender asymmetry at the end of the XXth century - the beginning of the XXIst century. The research methodology is based on the principles of historicism, systemicity and interdisciplinarity. The following methods have been used while carrying out the research: general scientific (analysis and synthesis, induction and deduction, analogy, generalization) and specially-historical (historiographical analysis, retrospective, historical-comparative). The gender approach, which is aimed to critically analyse the processes of constructing, interiorization and reproducing social representations of "masculine" and "feminine", as well as the peculiarities of the activity and interaction of men and women in various spheres of life through the prism of gender hierarchy, has been applied. The scientific novelty of the research consists in comprehending models of work-life balance in Norway in the context of gender equality. The Conclusions. During the end of the XXth century - the beginning of the XXIst century the three main models of work-life balance were implemented in Norway-the universal breadwinner, the universal caregiver and the caregiver parity. Norway, in contrast to many other European countries, offers its citizens a wide range of models of work-life balance. This kind of policy has its advantages and disadvantages, because the "freedom of choice" is often a smokescreen behind which there is a patriarchal structure reproduction. In particular, the "cash-for-care" system, which is the essential part of caregiver parity model, is based on the patriarchal ideology. The universal breadwinner model, which is the most popular among the Norwegians, does not promote gender equality as well, because it still puts the main part of caregiving on women. At the same time at the beginning of the XXIst century the dilemma of choosing a model of work-life balance obtained the intersectional connotation due to the large number of immigrants-representatives of other ethnic groups, cultures, and religions.
\end{abstract}

Key words: models of work-life balance, Norway, gender equality, state policy, feminism, childcare. 


\title{
МОДЕЛІ БАЛАНСУ МІЖ РОБОЧИМИ ТА СІМЕЙНИМИ ОБОВ'ЯЗКАМИ В НОРВЕГІЇ НАПРИКІНЦІ ХХ - НА ПОЧАТКУ ХХІ ст. У КОНТЕКСТІ ГЕНДЕРНОЇ РІВНОСТІ
}

\begin{abstract}
Анотація. Мета дослідження - описати, проаналізувати і порівняти різні моделі балансу між сімейними та робочими обов'язками, щчо впроваджувалися в Норвегї для усунення гендерної асиметрї̈ наприкінці XX-на початку XXI cm. Методологія дослідження спирається на принципи історизму, системності та міждисииплінарності. Під час дослідження було використано наступні методи: загальнонаукові (аналізу та синтезу, індукиії та дедукиї, аналогії, узагальнення) та спеціально-історичні (історіографічного аналізу, ретроспективний, історико-порівняльний). Також був застосований гендерний підхід, спрямований на критичний аналіз прочесів конструювання, засвоєння та відтворення суспільних уявлень про “чоловіче” $i$ “жіноче” й особливостей активності та взаємодії чоловіків і жінок у різних сферах життєдіяльності крізь призму гендерних ієрархічних зв'язків. Наукова новизна полягає у спробі аналізу моделей балансу між сімейними та робочими обов'язками у Норвегї̈ у контексті досягнення гендерної рівності. Висновки. Наприкіниі XX-на початку XXI cm. в Норвегії були впроваджені три основні моделі балансу між сімейними та робочими обов'язками - універсального годувальника, універсального піклувальника та рівного статусу піклувальника. Норвегія, на відміну від багатьох інших європейських країн, пропонує своӥм громадянам досить широкий вибір моделей балансу між роботою та приватним життям. Така політика має як переваги, так і недоліки, адже під ширмою “свободи вибору” нерідко відбувається відтворення патріархальних структур. Зокрема, саме на патріархальній ідеології заснована частина моделі рівного статусу піклувальника - схема готівка-за-піклування. Не сприяє гендерній рівності і найпопулярніша серед норвежців модель універсального годувальника, яка все ще покладає на жінку основні обов'язки догляду за дітьми. При изьоуу на початку XXI cm. проблема вибору моделі балансу між життям та роботою набула також інтерсекиійного характеру через значну кількість іммігрантів - представників інших етносів, культур, релігій.
\end{abstract}

Ключові слова: моделі балансу між приватним життям та роботою, Норвегія, гендерна рівність, державна політика, фемінізм, догляд за дітьми.

The Problem Statement. Nowadays the division of work between men and women is the central issue in gender equality policy development. Its roots are deep in historical development of the humankind. The most epochs of written history of the world were accompanied by the belief that women are inferior to men, they were moved to the private sphere and women's roles were considered as complimentary to those that men had. Despite the fact that today in many countries these preconceptions were reconsidered and weakened, they still have influence in society.

In the Nordic context, this issue remains inspite of the leading position of the Scandinavian countries in providing the gender equality policies in comparison with the rest of the world. For example, Norway still has a pay gap between men and women, gender segregation of work and education, gender issues related to violence and other problems to deal with (Lister, 2009 , p. 266). One of the most widespread problems is the asymmetry in the work-life balance between men and women - women still do the most of unpaid reproductive work, and this fact is one of the obstacles for achieving a gender equality.

The Analysis of Sources and Recent Researches. The analysis of the various aspects of the socio-economic policy of Norway in the gender context was the subject of the study for many researchers. But in the context of our study the works that cover the place of women in the Norwegian welfare state and the gender division of responsibilities in the household are of particular interest. The theory and practice of women-friendly welfare state, "a democratic family" and women-friendly policy can be found in the works of J. Ahlberg, C. Roman and S. Duncan (2008); A. Borchorst (2008); A. Borchorst and B. Siim (2008) and R. Lister (2009). 
The work of T. Rogg Korsvik (2011), as well as B. Bungum's and E. Kvande's (2013), is focused on the evolution of the Norwegian child-care policies and feminist activism.

In Ukrainian historiography there is the lack of the studies of approaches to solving the problem of work-life balance in Norway. At the same time, the study of the progressive Norwegian experience in this field from a historical perspective may be useful not only in the context of studying the socio-economic history of Norway, but also during the development of Ukrainian legislation, in particular, on a parental leave, etc.

The publication's purpose - to describe, analyse and compare different models of the work-life balance, which were implemented in Norway to remove the gender asymmetry at the end of the XXth century - the beginning of the XXIst century.

The Statement of the Basic Material. Studying the problem of achieving gender equality in Scandinavia, H. Hernes concludes that the welfare state, which is aimed at playing the main role in provision of socio-economic well-being of citizens, should be woman-friendly. Her explanation of this type of the state is as follows: "A woman-friendly state would enable women to have a natural relationship to their children, their work and public life... A woman-friendly state would not force harder choices on women than on men, or permit unjust treatment on the basis of sex. In a woman-friendly state women will continue to have children, yet there will also be other roads to self-realization open to them. In such a state women will not have to choose the future that demands greater sacrifices from them than are expected of men" (Borchorst \& Siim, 2008, pp. 214-219).

The idea of women-friendly state and its existence in Norway is a subject of the study for R. Lister. Analysing the achievements of Scandinavia in a gender equality in the context of women-friendliness, R. Lister challenges the notion about the "Nordic Nirvana" that sometimes is used in describing gender policies in the Scandinavian region. She concludes that now it is just a chimera and the Scandinavian states are far from the "women-friendly" welfare state, because women and men here are not equal in their rights, obligations and opportunities. Also, there is a problem with incorporation of immigrants that caused the new challenges in the gender issue (Lister, 2009, p. 266).

The concept of "women-friendly" welfare state is closely related to the principles of shaping the balance between work and private life, as well as the concept of democratic family and U. Beck's \& A. Giddens' theory of individualization.

The individualization theory is deeply connected with the weakening the traditional social structures that deal with gender, economic status, ethnicity etc. (Ahlbeg et al., 2008, p. 80). Due to the abolishment of normativity of the traditional social system individuals obtained the opportunity to shape their own lives and to choose the most preferable pattern of behaviour by themselves. In the family affairs individualization means appearances of the new type of family - "negotiated family" according to U. Beck - where people are not restricted by society and all the shape of their family relations depends on arrangements with each other (Ahlbeg et al., 2008, p. 80). A. Giddens suggests that in this type of family the relationships are "pure", because they are based on honesty, openness, negotiations and equality; they contribute to the democratization of the family (Ahlbeg et al., 2008, p. 80). But when it comes to the practice, individuals have to choose for themselves the pattern of behaviour and shape their model of balance between work and private life. This choice depends on both objective and subjective factors, among which are options proposed by the state, personal beliefs, economic situation, the level of education and self-development, etc. 
The Scandinavian countries worked hard to find an ideal balance among employment, interests of children and gender equality. But the construction of such a balance is not an easy task, because it is not stable. All its elements are in constant interaction with each other and under the influence of the surrounding world, where even the meaning of certain concepts, for example, of gender equality, constantly changes with the emergence of the new approaches and economic realities (Gislason, 2011, p. 13).

The long discussion on the ways of achieving of gender equality led to the emergence of many strategies, proposed by researchers on the basis of different approaches. Before analysing the work-life balance models and explanations for gender inequality, we should mention Wollstonecraft's dilemma that is based on the equality/difference division, which led to the private/public split (Borchorst, 2008, p. 27). This dilemma is focused on the women's place towards men. The central problem is either women should interiorize the male pattern of behaviour to achieve gender equality, or they are different and the roles between individuals should be redistributed according to their gender? This implies the following question - can we achieve gender equality, if we consider men and women as different human beings in a social dimension? (Borchorst, 2008, pp. 27-28).

In the late 1980-ies this dilemma was reconsidered and criticized strongly by the feminist researchers, which doubted the notion about the obligatory choice between sameness and differences. The majority of researchers consider this dilemma as a socially constructed phenomenon. In that period they started to argue that difference is opposite to sameness, but not to equality (Borchorst, 2008, pp. 28-29). In particular, J. Scott suggests that the view about opposition and irreconcilability between equality and difference was invented to restrict women's options (Borchorst, 2008, p. 28). It led to the appearance of different ways of achieving a gender equality, which refer to the approaches of sameness, as well as differences between men and women. The problem of integrating women at the labour market is in the central place here because it is connected directly with the shaping of work-life balance and division of responsibilities between men and women in the family.

This paper will focus on the Nancy Fraser's classification of work-life balance models for achieving gender equality. In general, she distinguishes the three ideal models, which have their own specificity (Borchorst \& Siim, 2008, p. 211). Each of these models has its own legislation innovations, which are the means of implementing these types of work-life balance into practice.

For example, the universal breadwinner model is based on the approach of sameness of men and women and, in this case, on predominance of the male behavioural pattern. So it requires from women to take over this type of behaviour (Borchorst \& Siim, 2008, p. 211; Borchorst, 2008, pp. 29-30).

In Norwegian legislation full-time day-care facilities are the means for implementing this model. This type of means is aimed at transfering the part of care responsibilities from family to the state and market. Having some problems with providing day-care facilities at the start of this initiative, nowadays Norway provides day-care facilities for the majority of children from 1 to 6 years old.

According to the universal breadwinner model, women have to enter the labour market and use childcare facilities, which have to be provided by the state (Borchorst \& Siim, 2008, p. 211; Borchorst, 2008, pp. 29-30). It makes possible for women to obtain the job and ensure their economic independence.

The caregiver parity model is based on the approach of gendered division of work. It aims at giving significance and evaluation to the reproductive responsibilities, which 
usually are considered as women's field of activity. This model includes different types of support to caregivers and aims at entitling those, who take reproductive responsibilities with the status of citizen caregivers (Borchorst \& Siim, 2008, p. 211; Borchorst, 2008, pp. 29-30). In legislation this model is represented by the cash-for-care scheme, which is supposed to be gender neutral. This scheme is a special type of allowance that is provided to those, who don't want to use day-care services and prefer home care. The men or women can stay at home for the period of child's growing up and receive the same amount of money as the state spends for a child in a day-care centre. This scheme was introduced in Norway in 1998 and had been very popular for the next 7 years. But after 2005 the level of its popularity decreased drastically (Bungum, 2013, p. 31). Nowadays such schemes are popular among the poorlyeducated low-income women-immigrants.

In contrast to the universal breadwinner, the universal caregiver model puts women's behavioural pattern in the centre. According to it, men should internalize female life patterns, sharing the reproductive work with women (Borchorst \& Siim, 2008, p. 211; Borchorst, 2008, p. 29-30). It is embodied in a parental leave and "daddy quotas" and gives the opportunity to both men and women to be engaged in the childcare, as well as to maintain the job and take part in different fields of a social life. In Norway the majority of fathers use this leave. Nowadays the duration of the leave for them is 15 weeks (from July 1, 2018).

Two of these work-life balance models fit to the type of society, which a socio-anthropologist A. N. Longva calls mono-gendered. This kind of the society, according to her, envisages that the model of behaviour of particular gender becomes leading and all individuals should try to act according to it (Longva, 2003, p. 158). So, in our case, the universal breadwinner model aims at making a male behavioural pattern a central one in the society, in contrast to the universal caregiver pattern, which promotes a female model of activity.

Back to the history of the emergence and development of different work-life balance models in Norway, it should be admitted that during the 1970 - 1980-ies Norwegian feminist activists (representatives of different organizations), who worked actively on the integration of women in the labour market, made a significant impact on it. T. Rogg Korsvik, who studies the influence of grassroots movements on the childcare policies in Norway, allocates three main organizations, which made a lot of progress in the legislative innovations implementation, embodied in a parental leave, daddy quotas and cash-for-care scheme, which now coexist and represent different approaches to understanding a gender equality.

The most conservative wing was represented by the Norwegian Housewives' Association. This organization had considered women as different from men and supported gendered roles, where breadwinning was the male pattern and care responsibilities belonged to females (Rogg Korsvik, 2011, p. 137).

The Association accepted complementarity of women's roles, but was trying to raise the level of importance of reproductive work by cash benefits for those families with kids, who did not use day-care facilities. Its members fought against a full-time daycare and quotas for fathers. This organization was the largest one - it had approximately 60000 members (Rogg Korsvik, 2011, p. 137). The Norwegian Housewives’ Association's activity contributed to the implementing the cash-for-care scheme as a means of strengthening the caregiver parity model.

The Labour Women represented the left-wing ideology and fought for the parental leave scheme for fathers and developing the wide network of the full-time day-care facilities. This organization had strong connections with the Labour Party (Rogg Korsvik, 2011, p. 137). 
The Women's Front representatives embodied the radical left wing and were struggling for the liberation of women through economic independence from men. It had 4000 members, which were strongly convinced, that free day-care facilities for all children and men's engagement into reproductive responsibilities would help to release female population from economic dependence (Rogg Korsvik, 2011, p. 137).

So, as we can see, during the 1970 - 1980-ies among Norwegian activists there were supporters of all the three models of work-life balance, but the most numerous was the Norwegian Housewives' Association, which represented the conservative wing. Considering this fact, it can be concluded that Norwegian authorities had a tendency to make reforms from above, because their activity was more progressive in this case, than the reforms of the Norwegian society.

As it was stated above, all three models have their supporters and critics. For example, $\mathrm{N}$. Fraser considers the universal breadwinner model as a means to achieve gender equality in capitalist post-industrial countries because of women's integration into breadwinning and decrease of men's wages that weakened the norm of male-breadwinner (Borchorst \& Siim, 2008, p. 211).

Analysing the consequences of the universal breadwinner model in the context of monogendered Norwegian urban society, A. N. Longva suggests that nowadays Norwegian authorities and media do their best to promote this model. They try to prompt women to interiorize a male behaviour by the notion that they are able to do all the things that men do. This policy led to the appearance of the concept of "strong women" and ensured the leading position of male behavioural pattern. This governmental policy is the consequence of the theoretical rethinking of womanhood, in particular, avoiding the biological explanations of women's status in the society (Longva, 2003, pp. 159-160).

The process of defamilialization (according to G. Esping-Andersen), which is provided by the day-care facilities, is also connected with implementation of the universal breadwinner model. Defamilialization made it possible for women to combine productive and reproductive work. In G. Esping-Andersen's opinion the rate of women's participation in the labour market in this region, which is approximately the same as men's, a high percentage of women in Parliament (30-50\% of MPs in national parliaments are females) and a low rate of single mothers were ensured by the defamilialization of women (Melby, Ravn \& Wetterberg, 2008, p. 6).

At the same time, the universal breadwinner model and the means of its implementation were criticized by some feminist activists and researchers. On the one hand, the situation when the state takes some part of childcare has become the subject of a constant controversy for those, who are convinced of the harmful impact of kindergartens on the development of children, at least the youngest ones. Their proposal is to limit the time spent by children in the kindergartens (Gislason, 2011, p. 15). In particular, the representatives of the Housewives' Association considered children as mothers' responsibility and for them the level of children's welfare was inversely proportional to the level of mother's employment. This preconception became the basis of their critics of full-time day-care facilities, which made it possible for women to obtain the full-time job (Rogg Korsvik, 2011, p. 139).

On the other hand, the new trend towards this issue is the emergence of religious-oriented kindergartens, which is a new and serious challenge to a society that tries not to restrict the parents in their desires, but at the same time, wants to have developed and socialized children (Gislason, 2011, p. 15).

The other group of critics of this model have shown the patriarchal basis of this model. Studying the reasons for the gender pay gap in the context of the family and childcare, 
I. Gislason shows the gender asymmetry in the family-friendly policy, stating that it still more concerned towards women and giving them the opportunity to combine paid and unpaid employment. Men are not yet considered as caregivers in this system. One of the reasons for women's lower wages is that they now take more responsibility for children's' welfare and homework and are seen as those, who are more responsible for the health and safety of children. This situation led to employers' belief that most women with children are not inclined to give priority to work and leave the family behind. In order to ensure competitiveness with men, women should be free from family responsibilities, but now even this does not lead to an equal pay. The pay gap has direct impact on the decision of the couple concerning the division of responsibilities. If it exists, the tendency for a woman to be responsible for the most of unpaid work will be continued, because it is more profitable for the family (Gislason, 2011, p. 19).

In the context of development of the universal caregiver model I. Gislason suggests that "unless we manage to change the traditional division of labour in families and at home, further progress will be blocked in other areas as well. And unless we balance the distribution of a parental leave and other care duties, the devaluing of women at the labour market will continue" (Gislason, 2011, p. 13).

As it was noted above, the Scandinavian governments tried to resolve the problem of an asymmetric distribution of childcare responsibilities on the basis of gender equality by the shared parental leave. The arguments for this scheme are as follows: when the mother and father take part in upbringing from a child birth, this would eliminate (or at least weaken) the discrimination of women at the labour market, because in such a system both parents will be absent at the workplace for a certain time after a child birth. In addition, this system also introduces the idea that fathers should take care of the child even after the parental leave. And it will be easier for them because a parental leave will help the father to become more confident in caring and generate the desire to spend more time with his children (Gislason, 2011, p. 22).

A parental leave plays a key role in many aspects. This is important not only for the health of the mother and child, but also makes it possible to establish an equal distribution of family responsibilities between the mother and father and contributes to the establishment of a special relationship between children and both parents, since both take care of them from the early childhood. At the same time, considering the system of argumentation of this system opponents, it can be stated that they insist on their right to choose the most preferable system including that, where the mother is a key figure in the children upbringing. In the economic sense, this system is also a ground for concern, given the fact that men can also choose a private life and childcare as their priority, pushing paid employment to the second place (Gislason, 2011, p. 16).

The universal caregiver model corresponds to the concept of "a double emancipation" which considers the equal parenthood as an attribute of the state welfare (Hearn et al., 2012, p. 35). According to this concept, a man and a woman have to share their obligations in private and public spheres, which include productive work, as well as reproductive, equally. If it happens, they both will be emancipated, because a "traditional" division of work excludes men from childcare and domestic work, and women - from the labour market (Hearn et al., 2012, p. 35; Borchorst \& Siim, 2008, pp. 214-215).

The universal caregiver model also correlates with H. Aarseth's research results. She studied the duty and passion in heterosexual couples and proposed a new scheme of work 
division that includes an equal responsibility of men and women for caring and housework: "In the place of a female provider of practical care, something different emerges as various domestic tasks are redefined as team-work and motivated within a wider scheme - that of a joint project" (Aarseth, 2007, p. 140). H. Aarseth connected this model with Giddens' theory on pure relations, where both in the couple do things together and she concluded that this division is partly free from "the gendered identities" (Aarseth, 2007, p. 140).

According to the recent research, a parental leave helped families to share childcare responsibilities more equally, but nowadays the situation is far from the equality. The researchers convinced that this is connected with fathers' reluctance to take this leave, a mother's reluctance to share it with a father, and also it is under the influence of economic factors, especially, the gender pay gap (Gislason, 2011, p. 23).

The caregiver parity model is the most controversial model of work-life balance. While the previous two models are based on the parental leave with "daddy quotas" and day-care centres, which encourage men and women to be engaged in productive and reproductive work; caregiver parity divides the couple into breadmaker and caregiver by introducing cash-for-care scheme. This scheme was presented as an alternative choice for the Norwegian families, because it provides the opportunity to spend more time with the family and to raise the children without day-care facilities, as well as puts those, who use the state-funded kindergartens in an equal position with those, who don't want to do it, by compensating the money that the state spends to maintain children in day-care centres (Bungum \& Kvande, 2013, pp. 32-33). The cash-for-care scheme does not require from parents to participate in the labour market and, in contrast to the previous models, it gives no opportunity to combine a paid job with childcare (Bungum \& Kvande, 2013, pp. 32-33).

A. L. Ellingster and A. Leira stated that different political forces were engaged in shaping and developing a parental legislation in Norway (Bungum \& Kvande, 2013, p. 33). The cashfor-care scheme is strongly supported by the Christian Democratic and Liberal forces, which consider it as a compensation for unpaid reproductive work. Under the guise of freedom of choice and because of the law rate of such allowances the idea of gender neutral option for one in a couple turned into the option for women with a low income or unemployed (Bungum \& Kvande, 2013, pp. 34-35).

B. Bungum and E. Kvande discovered that there were 3 phases of using cash-for-care allowances. The first phase is characterized by heterogeneity of the recipients - from the beginning people from different backgrounds used it. In that case the discussion appeared "whether the cash-for-care scheme would undermine the dual-earner model by encouraging mothers to "return to the kitchen" and leave paid work?" (Bungum \& Kvande, 2013, p. 49). Later it was shown, that the level of usage of family allowances depends on the educational background (Bungum \& Kvande, 2013, p. 49).

The second phase is characterized by the significant decline of cash-for-care due to the introduction of "the day-care guarantee" in 2003, so this made it possible to B. Bungum and E. Kvande to conclude that since this time "the public debate on cash for care slowly turned from gender towards class and ethnicity” (Bungum \& Kvande, 2013, p. 49).

The third phase has clearly shown that this scheme is popular among immigrants and poorly-educated women (so, this became an intersectional issue), and in this time the discussion about ethnicity and socialization of immigrants appeared (Bungum \& Kvande, 2013, pp. 32-33, 50). And because of this situation the Norwegian authorities want to change the conditions of cash-for-care scheme by reducing the age of children, whose parents can 
receive the allowance from 3 to 2 years. This measure is aimed at increasing the amount of women at the labour market and to raise the level of immigrant's children attending day-care centres. But this proposal remains controversial (Bungum \& Kvande, 2013, p. 50).

Now the majority of Norwegians prefers daytime childcare facilities and keeps the universal breadwinner model of work-life balance. According to statistics, there were: “... approximately 6100 kindergartens in Norway in 2015. Over half of these were private, accounting for $49 \%$ of all kindergarten places. A total of 284000 children now have a kindergarten place, and the kindergarten coverage now appears to have stabilised: $90 \%$ of children aged 1-5 now have a kindergarten place, which is more than five times higher the number in 1980" (Modig \& Kristiansen, 2016, p. 20).

Analysing the figures for older children (3-5 years), it can be concluded that most of them attend kindergarten. Over the last few years, the trend towards a reduction in the use of the cash-for-care scheme is maintained. The statistics is as follows: the number of children receiving a payment has decreased "from 86700 in 2000 to 27700 in 2011. In 2012 cash benefits to two-year-olds were stopped and in September 2015, 13200 children received cash benefits, amounting to $24 \%$ of all one-year-olds" (Modig \& Kristiansen, 2016, p. 20).

The Conclusions. The discussion about the ways of achieving gender equality remains in the Norwegian society and gets new challenges, caused by economic issue (pay gap, glass ceiling, etc.), consequences of different childcare approaches, immigration flow and other conditions.

Despite the existent problems, for the last few decades Norwegian men and women obtained more options to shape their lives combining labour activity and housework. The legislative innovations made it possible for men to be engaged in childcare and for women to be full-fledged workers by implementing day-care facilities and parental leave with "daddy quotas". It resulted in increase of the birth rate and drop of the single mother's poverty level.

During the end of the XXth century - the beginning of the XXIst century the three main models of work-life balance were implemented in Norway - the universal breadwinner, the universal caregiver and the caregiver parity. The specific feature of Norwegian childcare policy in comparison with other Nordic countries is that in Norway is the wide range of means that give people the opportunity to choose the work-life balance, which is the most preferable for them. This system has its pros and cons, which can be expressed in opposition "freedom of choice" vs "patriarchal structure reproduction". While the parental leave and day-care centres are aimed at giving women the opportunity to combine a paid job and caregiving, under the current socio-economic circumstances the cash-for-care system reproduces patriarchal structures. It should be admitted, that the universal breadwinner model, which is the most preferable among the Norwegians, also can be considered as an obstacle for achieving a gender equality, because it still considers women as the key figures in childcare and just tries to help them to combine productive and reproductive work.

It can be also concluded, that the dilemma of work-life balance shaping has obtained an intersectional connotation because of the huge flow of immigrants, a strong influence of class, ethnicity, religion and other factors on the choice of individuals.

Acknowledgments. Sincere thanks to the organizers and sponsors of the International Summer School at the University of Oslo (Norway) (2017).

Funding. The author received a scholarship for being a participant at the International Summer School at the University of Oslo (Norway) (2017) and an opportunity to work at the University's library during working on this article. 


\section{BIBLIOGRAPHY}

Aarseth, H. (2007). Between Labour and Love: The Re-erotization of Home-making in Egalitarian Couples within a Nordic Context. NORA, (15(2-3)), 133-143. doi: 10.1080/08038740701511669. [in English]

Ahlberg, J., Roman, C., \& Duncan, S. (2008). Actualizing the "democratic family"? Swedish policy rhetoric versus family practices. Social Politics, (15 (1)), 79-100. doi: 10.1093/sp/jxn003. [in English]

Borchorst, A. (2008). Women-friendly policy paradoxes? Childcare policies and gender equality visions in Scandinavia. In K. Melby, A.-B. Ravn \& C. C. Wetterberg, (Eds.), Gender equality and welfare politics in Scandinavia (pp. 27-42). Bristol: The Policy Press. [in English]

Borchorst, A., \& Siim, B. (2008). Women friendly policies and state feminisms: Theorizing Scandinavian gender equality. Feminist Theory, (9), 207-224. doi: 10.1177/1464700108090411. [in English]

Bungum, B., \& Kvande, E. (2013). The rise and fall of "cash for care" in Norway: changes in the use of child-care policies. Nordic Journal of Social Research, (4), 31-54 doi: 10.7577/njsr.2065. [in English]

Gislason, I. V. (2011). Introduction. In I. V. Gislason, G. B. Eydal (Eds.), Parental leave, childcare and gender equality in the Nordic countries (pp. 13-30), Copenhagen: TemaNord. [in English]

Hearn, J., Nordberg, M., Andersson, K., Balkmar, D., Gottzen, L., Klinth, R., Pringle, K., \& Sandberg, L. (2012). Hegemonic Masculinity and Beyond: 40 Years of Research in Sweden. Men and Masculinities, (15), 31-55. doi: 10.1177/1097184X11432113. [in English]

Lister, R. (2009). A Nordic Nirvana? Gender, Citizenship, and Social Justice in the Nordic Welfare States. Social Politics, (16 (2)), 242-278.doi: 10.1093/sp/jxp007. [in English]

Longva, A. N. (2003). The Trouble with Difference: Gender, Ethnicity and Norwegian Social Democracy. The multicultural Challenge Comparative Social Research, (22), 153-175.doi: 10.1016/ S0195-6310(03)22006-8. [in English]

Melby, K., Ravn, A.-B., \& Wetterberg, C. C. (2008). A Nordic model of gender equality? Introduction. In K. Melby, A.-B. Ravn \& C. C. Wetterberg, (Eds.), Gender equality and welfare politics in Scandinavia (pp. 1-26). Bristol: The Policy Press.

Modig, I., Kristiansen, J. E. (2016). This is Norway 2016. What the figures say. URL: https://bit.ly/2YQwJLm. [in English]

Rogg Korsvik, T. R. (2011). Childcare policy since the 1970s in the "most gender equal country in the world”. European Journal of Women's Studies, (18(2)), 135-153. doi: 10.1177/1350506810394615. [in English]

The article was received on August 06, 2019. Article recommended for publishing 20/05/2020. 